\title{
BOREHOLE LOGGING INVESTIGATIONS FOR PLANNING OF REMEDIAL ACTION ON WATER SUPPLY WELLS SHOWING DETERIORATION IN GROUNDWATER QUALITY.
}

\author{
Kurt Klitten \\ Senior Scientist, Department of Hydrology and Glaciology, Geological Survey of Denmark \& \\ Greenland; Thoravej 8, DK2400 Copenhagen NV, Denmark.
}

\section{INTRODUCTION}

Comprehensive wireline logging investigation is necessary for providing the information needed for the evaluation of the possibility for relief of a deterioration in the quality of the water from a well, and for the choice and design of a remedial solution. Two different techniques are available as remedial solutions both aiming to improve the quality of the water produced from the well. One is a reconstruction of the well in order to close off the inflow of water with unwanted quality. This solution however is only feasible if the remaining inflow of water is sufficient in quantity and quality and will continue to be so. In cases where the unwanted water is not occurring in a separate aquifer, thus not separated from the wanted water by impermeable layers, a blockade of the unwanted inflow will not ensure a sustainable improvement of the situation. A more feasible solution can then be an arrangement of separation pumping by using two pumps and mutually balance the discharge between the two pumps in order to pump unwanted water from one pump and wanted water from the other one. This solution like the first one, is feasible only if the production capacity of water with acceptable quality, is sufficient. An investigation of four wells on a well field at a waterworks with deterioration in water quality is presented including conclusions and recommendations on remedial action:

\section{WELL FIELD AT GLOSTRUP WATERWORKS}

Hydrogeology: The quaternary deposits are $5-10 \mathrm{~m}$ thick consisting mainly of boulder clay till resting on 30-50 $\mathrm{m}$ tertiary Danian bryozoan limestone underlain by Cretaceous chalk. A significant difference in depth to top chalk between the Southern and the Northem part of the well field has previously been interpreted as the occurrence of a west-east striking fault. The terrain elevation of the well field is about $+12 \mathrm{~m}$ and the watertable is generally lowered to about $+2 \mathrm{~m}$.

Problem: Since 1993 the content of Nickel in water delivered from the waterworks has increased to above the permissible level of $20 \mu \mathrm{g} / \mathrm{tt}$. reaching $34 \mu \mathrm{g} / \mathrm{tt}$. in May 1994. The water is produced from four wells, Hol, Ho3, Ho2 and Ho5, situated within $500 \mathrm{~m}$ approximately along a line and in the mentioned order from Southwest towards Northeast. Increasing Nickel is observed in the water produced from each of the four wells with the highest values occurring in the two north-eastern wells, $\mathrm{Ho} 2$ and $\mathrm{Ho} 5$ with respectively 130 and $197 \mu \mathrm{g} / \mathrm{lt}$. Therefore, production from these two wells were stopped, Ho5 in May 1994 and Ho2 in November 1994, though remedial pumping was continued on $\mathrm{Ho} 5$ due to occurrence of pesticide in this well.

Investigations: Logging investigations and sampling of water for analysis were done in $\mathrm{Ho} 5$ in March-April 1995, in Hol and Ho3 in August-October 1995, and finally in Ho2 in April 1996. The logging programme in each well consisted of the following logs before pumping: Fluid conductivity \& temperature, focused resistivity, natural gamma, calliper, discrete heat pulse flow test; and during pumping: Fluid conductivity \& temperature logs and impeller flow $\log$. The composite log sheet on Figure I illustrates the log suite, though the discrete results from the heat pulse flow test are not included on the standard composite log sheet. 


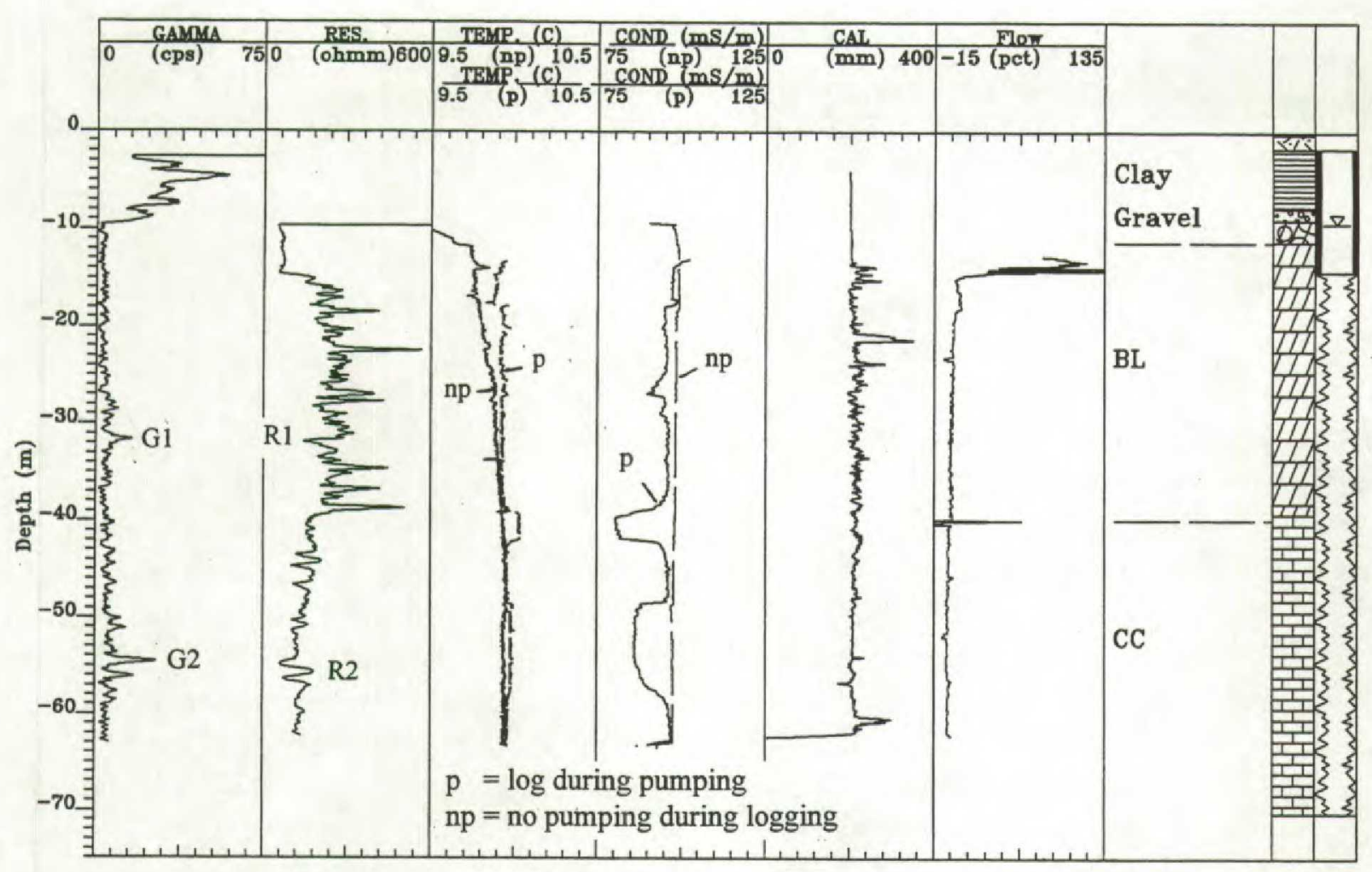

Figure I: Log suite from well Ho5, Glostrup Waterworks.

\section{Findings on geology:}

- The boundary between the Danian bryozoan limestone (BL) and the Cretaceous chalk (CC) is unambiguous reflected on the resistivity log by a significant change in the resistivity level and pattern due to the difference in the lithology of the two rocks. The bryozoan limestone has generally a high and varying resistivity compared to the resistivity of the chalk, the latter being a rather homogeneous and soft rock with a generally high porosity (above $50 \%$ ) opposite to the bryozoan limestone which is a bedded and generally more indurated rock with the layer thickness most frequently varying between 5 and $30 \mathrm{~cm}$ and the layers showing porosities between 0 and $50 \%$. The correlation of the resistivity logs from the four wells on Figure II shows that the BL-CC boundary occurs nearly at the same level, i.e. $-24 \mathrm{~m}$ to $-27 \mathrm{~m}$. This observation is in contradiction to previous perception of a west-east striking fault between the well $\mathrm{Ho} 3$ and $\mathrm{Ho} 2$ with a $20 \mathrm{~m}$ downthrow of the BL-CC boundary towards south.

- The BL-CC boundary is not reflected on the gamma-logs, see Figure II.

- A significant double gamma-peak (G2) is seen in the CC at a depth of approximately $15 \mathrm{~m}$ below the BL-CC boundary and with corresponding resistivity minima as significant markers (R2) on the resistivity-logs. This double marker horizon can most probably be correlated to the Kjoelbygaard Marl, an upto $2 \mathrm{~m}$ thick layer regionally occurring in the uppermost part of CC. Another gamma-marker (G1) occurs approximately $8 \mathrm{~m}$ above the BL-CC boundary and also with a corresponding resistivity marker (R1) on the resistivity logs.

- The marker horizons in the $\mathrm{BL}$ and in $\mathrm{CC}$ indicate a remarkable concordance to the $\mathrm{BL}-\mathrm{CC}$ boundary.

\section{Findings on inflow distribution:}

The main inflow zones and their contribution in percentage of discharge are shown on the gamma-logs on Figure II together with the original depth of the wells and the casing depth. 
- Well Ho5 has nearly all the inflow from top of BL. Obviously, a remarkable hydraulic watershed occurs at the BL-CC boundary since the flow is downwards in the chalk section towards the bottom of the well even during a discharge from the well of $35 \mathrm{~m}^{3} /$ hour, see also Figure $\mathrm{I}$.

- The other three wells have considerable inflow from the chalk, most significantly in $\mathrm{Hol}$ and Ho3 (respectively $79 \%$ and $82 \%$ ) which obviously both have intersected a highly waterbearing zone located approximately $10 \mathrm{~m}$ below the G2-R2 marker horizon in the chalk.

- Originally, Ho5 has penetrated that zone also and still seems to have hydraulic connection to the zone resulting in the watershed in the well during discharge, i.e. with downwards flow in the chalk section caused by the production discharge from the other wells, Hol and Ho3.

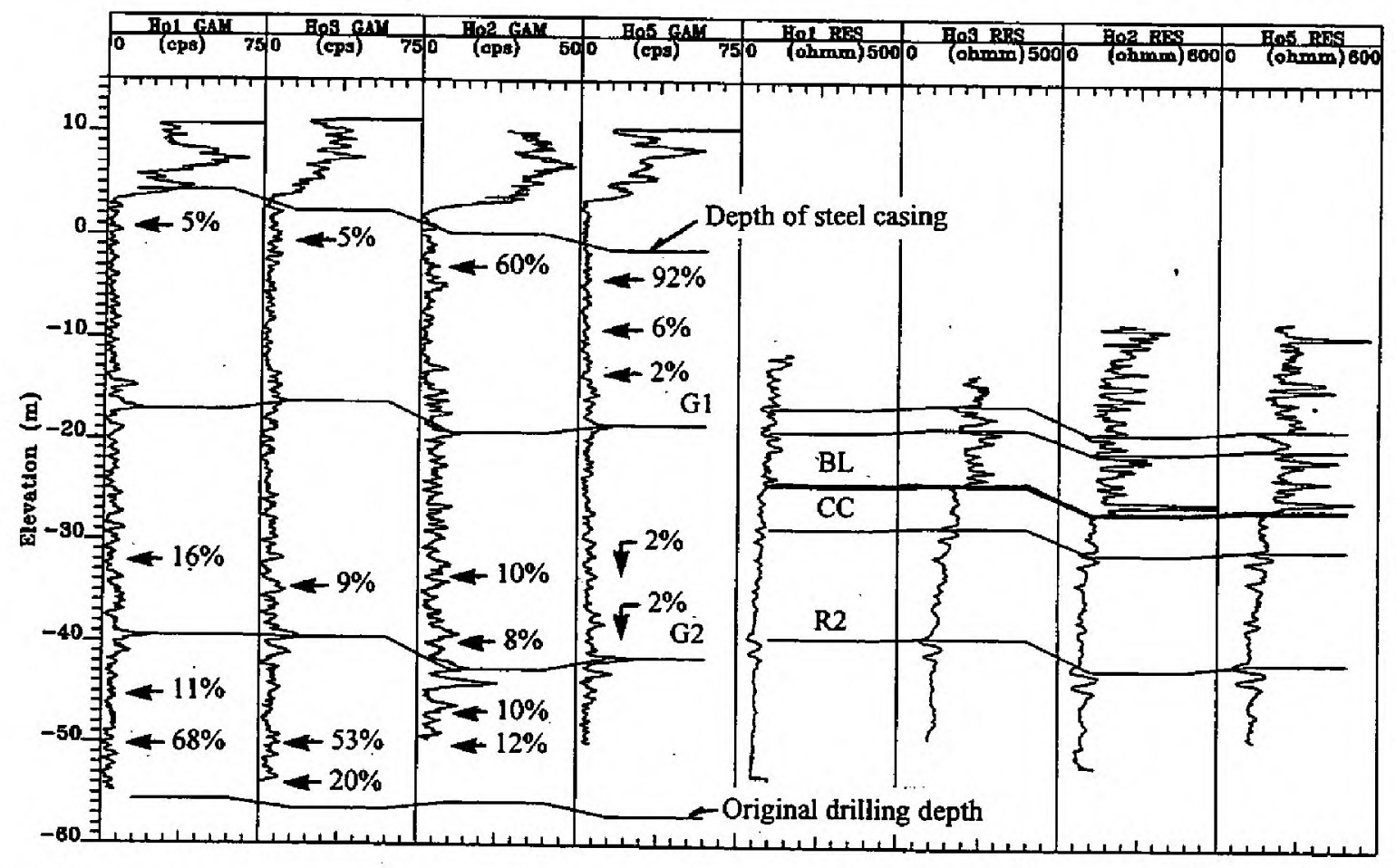

Figure II: Correlation of gamma-logs and of resistivity-logs from four wells, Glostrup Waterworks, and inflow zones in the wells and their contribution to the discharge in percentage.

Findings on hydraulic short-circuit (internal flow) in non-pumping situation:

Hydraulic short-circuit in non pumping wells penetrating different aquifers is quite common on well fields with discharge from other wells. During the investigation of the four wells on the Glostrup well field the production pumping from $\mathrm{Hol}$ and $\mathrm{Ho} 3$ and the remedial pumping from Ho5 was continued except during the investigation in the respective wells.

- Accordingly, the heat pulse tests had shown the existence of an internal flow in the three wells, $\mathrm{Hol}, \mathrm{Ho} 3$ and $\mathrm{Ho} 5$, between the upper part of the BL and the highly permeable zone in the $C C$ resulting in a downwards flow of respectively $1100 \mathrm{lt}$./hour, $1800 \mathrm{lt}$./hour and 850 1t./hour. No flow was registered by the heat pulse flow test in well Ho2. However, temperature- and fluid conductivity $\log$ in Ho2 do indicate a downwards flow also in this well which therefore must be less than the detection limit of the heat pulse flow meter, i.e. less 10 $\mathrm{cm} /$ minute equal to less $200 \mathrm{lt}$./hour in the 8 " diameter well.

\section{Water sampling and findings on water chemistry conditions:}

The internal flow in the wells from the upper limestone aquifer downwards to the chalk aquifer during stop of pumping makes a representative water sampling at different depths complicated. 
The fluid conductivity and temperature logs from well Ho5, seen on Figure I, illustrate the complicated situation: The two logs before pumping., i.e. while the remedial pumping was stopped, compared to the same logs measured about $1 / 2$ hour after starting pumping with a discharge of $35 \mathrm{~m}^{3} /$ hour, reflect the following two situations:

- During stop: The water from top BL, with a conductivity of $98 \mathrm{mS} / \mathrm{m}$ and a temperature of $9.74 \mathrm{C}^{\circ}$, is flowing downwards to the bottom of the well but is diluted by a very small inflow with lower conductivity and higher or same temperature at the depths of $18 \mathrm{~m}, 27 \mathrm{~m}, 40 \mathrm{~m}$ and $49 \mathrm{~m}$ resulting in a final conductivity of $94 \mathrm{mS} / \mathrm{m}$ at bottom and a temperature of $9.93 \mathrm{C}^{\circ}$.

- During pumping ( pump at $12 \mathrm{~m}$ depth): In the limestone section between $40 \mathrm{~m}$ depth and 18 $m$ depth is seen a limited inflow and upwards flow of water only. This water has a slightly lower conductivity than the previously downwards flowing topwater but with a slightly higher temperature. The inflow at $18 \mathrm{~m}$ and the main inflow at $14.5 \mathrm{~m}$ increase the conductivity and the temperature even to a slightly higher level than observed during the previous downflow of topwater. In the chalk section below $40 \mathrm{~m}$ occurs a very limited downwards flow from inflow zones at $40 \mathrm{~m}$ and at $49 \mathrm{~m}$ with water having lower conductivity and higher temperature than the originally topwater still remaining in this section of the well . The inflowing water from those two zones has obviously moved from respectively $40 \mathrm{~m}$ to $42 \mathrm{~m}$ and from $49 \mathrm{~m}$ to $57 \mathrm{~m}$ depth during the $1 / 2$ hour since the pump was started.

- Water samples from $20 \mathrm{~m}$ depth in all the four wells taken in a non pumping situation represent the internal downwards flowing topwater, i.e. the water in the upperpart of the bryozoan limestone aquifer, which shows Nickel content in the range of 210 to $240 \mu \mathrm{g} / \mathrm{lt}$.

- The Nickel content in the produced water from each of the wells during the normal production situation was in November 1994 observed to be: $26 \mu \mathrm{g} / \mathrm{tt}$ in the wells Hol and Ho3, which have their main inflow from the chalk aquifer, whereas the $\mathrm{Ho} 2$ and $\mathrm{Ho} 5$ showed high concentration of Nickel, respectively 130 and $197 \mu \mathrm{g} / \mathrm{lt}$. in accordance to, that these wells mainly produce from the upperpart of the bryozoan limestone aquifer.

\section{Conclusion and remedial action to be taken:}

The Nickel problem of this well field is caused by an inflow to the wells of water from the upperpart of the bryozoan limestone aquifer having Nickel concentration in the range of 210$240 \mu \mathrm{g} / \mathrm{t}$. A highly waterbearing zone occurs in the Cretaceous chalk and at a depth of $63-64 \mathrm{~m}$, i.e. about $25 \mathrm{~m}$ below top of chalk and approximately $10 \mathrm{~m}$ below the Kjoelbygaard Marl layers. The future production of groundwater from the well field is suggested to be based only on this productive zone in the chalk aquifer. Accordingly, the construction of the four wells will be changed by installing a PVC-pipe with screen and sealing off the bryozoan limestone.

The experiences from $\mathrm{Hol}$ and Ho3, which since 1967 and 1948 have been producing more than $80 \%$ of their discharge from the chalk aquifer, indicate that the produced water after the reconstruction of the well field most probably will have Chloride and Fluoride content in the range of respectively $200-300 \mathrm{mg} / \mathrm{tt}$. and $2-2.5 \mathrm{mg} / \mathrm{t}$., whereas Sulphate and Nickel will decrease to values in the range of respectively $50-150 \mathrm{mg} / \mathrm{lt}$. and $0-5 \mu \mathrm{g} / \mathrm{lt}$. Therefore, the suggested reconstruction will solve the Nickel problem but will create a Fluoride problem instead. However, it is considered to solve this Fluoride problem by mixing with water passing nearby in a main pipe from another waterworks and having all the quality parameters below the permissible limit thus also low Fluoride content. It would not be similarly cost effective to solve the actual Nickel problem of this well field by applying the same dilution strategy instead of reconstruction of the wells simply because of less volume of dilution water necessary for bringing the Fluoride below the permissible level than for arriving to acceptable Nickel content. 